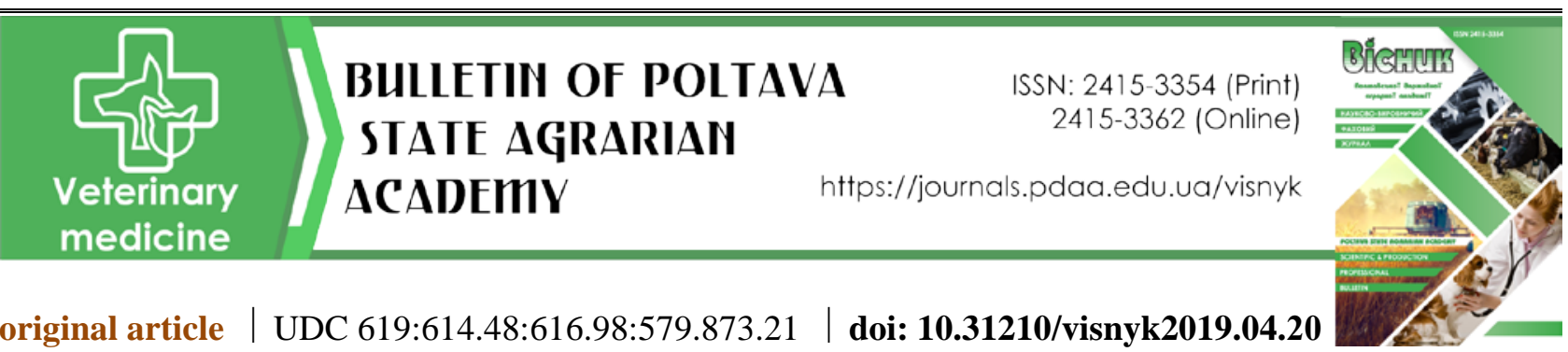

BACTERICIDAL PROPERTIES OF THE “DOROSEPT SUPER”AGENT FOR MYCOBACTERIA

A. P. Paliy,

ORCID ID: 0000-0002-9193-3548,E-mail: paliy.dok@gmail.com,

A. I. Zavgorodniy,

ORCID ID: 0000-0003-3563-0478,

National Scientific Center the "Institute of Experimental and Clinical Veterinary Medicine”, 83, Pushkinska str., Kharkiv, 61023, Ukraine

A. O. Bondarchuk,

ORCID ID: 0000-0002-4647-5541,

Kharkiv State Zooveterinary Academy, 1, Academichna str., Kharkiv, 62341, Ukraine

At present, disinfectants, which are used in livestock buildings, are different as to concentration of active substances, composition, application and a number of other properties. Most of them are imported commercial products. The relevance of the research is to replace them on the domestic market with more effective, safe and cost-efficient preparations. Such products must be highly effective and have a wide range of bactericidal, virucidal, fungicidal and sporocidal action. The improvement of livestock's health after infectious diseases, especially tuberculosis, which causes significant economic losses to this sector and threatens human health, is one of the important tasks of veterinary medicine specialists. The spreading of tuberculosis causal agents and atypical mycobacteria in the environment demands from specialists to use highly effective antimicrobial preparations to prevent further persistence of these microorganisms, as well as infecting farm animals. Ukrainian and foreign manufacturers recommend a great number of disinfectants, which are rather effective in the prevention and elimination of most infectious diseases. However, it should be noted that not all disinfectants are effective enough for tuberculosis infection. This paper presents the study results of the bactericidal properties of the "DOROSEPT SUPER" disinfectant as related to Mycobacterium fortuitum, as well as Mycobacterium bovis on test objects. The suspension method has shown that Mycobacteria fortuitum die after applying aqueous disinfectant solution at a concentration of $1.0 \%$ and exposure of 1 hour. After the treatment of wooden, batiste, metal, tile and glass test objects, which were contaminated with $M$. bovis, the viability of the latter ceased after 24 hours under the influence of $3 \%$ preparation concentration. Moreover, while applying an aqueous solution to the same test objects in an operating mode of $1.0 \%$ - 24 hours, mycobacteria died in all cases, except those that were applied to wooden surface. The results of biological study of the "DOROSEPT SUPER" disinfectant were also presented in the article.

Key words: disinfectant, mycobacteria, tuberculosis, concentration, exposition.

\title{
БАКТЕРИЦИДНІ ВЛАСТИВОСТІ ЗАСОБУ «DOROSEPT SUPER» ЩОДО МІКОБАКТЕРІЙ
}

\section{А. П. Палій, А. І. Завгородній,}

Національний науковий центр «Інститут експериментальної та клінічної ветеринарної медицини», м. Харків, Україна

А. О. Бондарчук,

Харківська державна зооветеринарна академія, м. Харків, Україна

Нині дезінфікуючі засоби, щзо використовуються у тваринницьких приміщеннях, різні за кониентрацією діючих речовин, складом, застосуванням та іншими властивостями. Більшість з них $\epsilon$ 


\section{ВЕТЕРИНАРНА МЕДИЦИНА}

імпортними продуктами. Вкрай актуально їх замінити на вітчизняному ринку ефективними, безпечними $і$ економічними препаратами. Це мають бути високоефективні засоби, з широким спектром бактерицидної, віруліщидної, фунгіџидної і спороиидної дії. Одним з важливих завдань фахівиів ветеринарної медицини є запобігання інфекиійним захворюванням у твариннищтві, особливо від туберкульозу, який завдає иій галузі значних економічних збитків і загрожує здоров'ю людей. Значне поширення у довкіллі збудників туберкульозу й атипових мікобактерій вимагає від спеціалістів застосування високоефективних антимікробних препаратів, щоб запобігти подальшій персистениіі цих мікроорганізмів, а також інфікуванню сільськогосподарських тварин. Вітчизняні та закордонні виробники рекомендують велику кількість дезінфектантів, які $\epsilon$ досить ефективними при профілактичі та ліквідації більшості інфекиійних захворювань. Водночас потрібно зазначити, щуо не всі деззасоби достатньо ефективні при туберкульозній інфекиії. У ціий роботі наведені результати досліджень бактерицидних властивостей дезінфікуючого засобу «DOROSEPT SUPER» щзодо Mycobacterium fortuitum, a також Mycobacterium bovis на тест-об'єктах. Суспензійним методом встановлено, ще Мусовасterium fortuitum гинуть при застосуванні водного розчину деззасобу при концентрації 1,0\% та експозииії 1 година. У разі нанесення препарату на дерев'яні, батистові, металеві, плиткові та скляні тест-об'єкти, які були контаміновані M. bovis, життєздатність останніх припинялася через 24 години при дії препарату в $3 \%$ кониентрачії. Водночас при нанесенні водного розчину на ті ж самі тест-об'єкти в робочому режимі 1,0\% - 24 години мікобактерії гинули у всіх випадках, окрім тих, які були нанесені на дерев'яну поверхню. Також у статті наведені результати біологічного дослідження дезінфікуючого засобу «DOROSEPT SUPER».

Ключові слова: дезінфікуючий засіб, мікобактерії, туберкульоз, кониентрачія, експозиція.

\section{БАКТЕРИЦИДНЫЕ СВОЙСТВА СРЕДСТВА «DOROSEPT SUPER» ПО ОТНОШЕНИЮ К МИКОБАКТЕРИЯМ}

А. П. Палий, А. И. Завгородний,

Национальный научный центр «Институт экспериментальной и клинической ветеринарной медицины», г. Харьков, Украина

А. А. Бондарчук,

Харьковская государственная зооветеринарная академия, г. Харьков, Украина

На сегоднямний день дезинфищируюшие средства, используемые в животноводческих помещениях, различные по кониентрачии действующих веществ, составу, применению и другим свойствам. Большинство из них представлены импортныли продуктами. Крайне актуально их заменить на отечественном рынке эффективными, безопасными и экономичными продуктами. Они должны быть высокоэффективными средствами, обладающими широким спектром бактерицидного, вирулииидного, фунгищидного и спороиидного действия. В данной работе приведены результаты исследований бактерицидных свойств дезинфицирующего средства "DOROSEPT SUPER» на Mycobacterium fortuitum, a также Mycobacterium bovis на тест-объектах. Суспензионным методом установлено, что Мусоbасterium fortuitum погибают при применении водного раствора дезсредства при концентрации 1,0\% и экспозиции 1 час. При нанесении на деревянные, батистовые, металлические, плиточные и стеклянные тест-объекты, которые были контаминированы M. bovis, жизнеспособность последних прекращалась через 24 часа при воздействии препарата в $3 \%$ концентрации. Наряду с этим при нанесении водного раствора на те же тест-объекты в рабочем режиме 1,0 \% 24 часа микобактерии погибали во всех случаях, кроме тех, которые были нанесены на деревянную поверхность. Также в статье приведены результаты биологического исследования дезинфицирующего средства «DOROSEPT SUPER».

Ключевые слова: дезинфицирующее средство, микобактерии, туберкулез, конщентрация, экспозиция.

\section{Вступ}

Туберкульоз тварин представляє як серйозну епідемічну, так і епізоотологічну небезпеку та має широке розповсюдження на території багатьох країн світу $[11,20]$.

У системі боротьби з туберкульозною інфекцією гостро постають питання щодо експресдіагностики та ранньої профілактики виникнення цього захворювання, боротьба з мультирезистентними формами інфекції, розробка ефективних вакцин [4], а також застосування високоефективних 


\section{ВЕТЕРИНАРНА МЕДИЦИНА}

дезінфікуючих засобів у комплексі ветеринарно-санітарних заходів [1, 12].

Вчасне та повсюдне впровадження науково обгрунтованих програм боротьби з туберкульозом $є$ не лише соціально важливим аспектом, але й передбачає отримання суттєвих економічних дивідендів [16].

Останнім часом проведено низку досліджень щодо пошуку та розробки ефективних протитуберкульозних дезінфектантів з різних хімічних груп. Оцінюючи летючі хімічні речовини, було визначено, що ацетон (22,5 \% - 24 години), гідроксид амонію $(1,0 \%-36$ годин), хлороформ $(0,5 \%$ - 48 годин), етиловий спирт (17,5\% - 48 годин) і ксилол $(3,0 \%-48$ годин) інактивують мікобактерії M. bovis, тому можуть бути потенційно корисними для тваринницьких господарств [17].

Найбільш ефективними та поширеними деззасобами є альдегідні сполуки, біоцидна дія яких полягає в руйнації поверхневих структур мікобактерій, утворенні в цитоплазмі вакуолей та осміофільних включень. У разі дії на мікобактеріальні клітини альдегідного дезінфікуючого препарату виникають комплексні незворотні зміни структурних елементів мікобактерій, що призводять до повної загибелі мікроорганізмів [2, 6].

Поряд з цим встановлено наявність туберкулоцидної дії і в інших деззасобів, визначено ефективні режими їхнього застосування як у лабораторних, так і виробничих умовах $[2,18]$.

Виявлено, що оцтова кислота $є$ ефективним мікобактерицидним засобом, навіть проти дуже стійкого, клінічно важливого комплексу Mycobacterium abscessus. [10]. Визначена ефективність ультрафіолетового випромінювання для знищення мікобактерій в обмежених приміщеннях [14]. Дослідження газової плазми, антимікробних поверхонь і парових систем стали цікавими альтернативами звичайним дезінфектантам [3].

Бактерицидний ефект деззасобів залежить не лише від режимів їхнього застосування, але й від наявності біологічного навантаження [5].

Актуальним залишається питання вибору тестової культури при апробації туберкулоцидних властивостей деззасобів. Повідомляється, що культура Mycobacterium smegmatis не $\epsilon$ адекватною моделлю для тестування активності дезінфікуючих засобів проти мікобактерій [9], а також, що культура мікобактерій M. chelonae та M. abscessus є більш резистентною, ніж M. smegmatis, a M. terrae більш стійка, ніж M. bovis (штам BCG) [8]. Найбільш стійкою культурою до дії деззасобів вважається M. tuberculosis [13].

Збільшення інвестицій у протитуберкульозні заходи, розробка нових антимікробних препаратів, допоміжних методів лікування та діагностики є найкращою можливістю контролювати це інфекційне захворювання [21].

Метою наших досліджень було виявити в лабораторних умовах бактерицидні властивості дезінфікуючого засобу «DOROSEPT SUPER» щодо Mycobacterium fortuitum (шт. 122) та Mycobacterium bovis (шт. Vallee).

\section{Матеріали і методи досліджень}

Експериментальні дослідження проводили згідно з методичними рекомендаціями «Визначення бактерицидних властивостей дезінфікуючих засобів, проведення дезінфекції та контроль її якості при туберкульозі сільськогосподарських тварин»)», що затверджені науково-технічною радою Державного комітету ветеринарної медицини України 20.12.2007 p.

Бактерицидні властивості деззасобу «DOROSEPT SUPER» визначали щодо збудника туберкульозу M. bovis та атипових мікобактерій, які вирощували на середовищі Павловського протягом, відповідно, 30-45 та 14-21 діб за температури $37^{\circ} \mathrm{C}$. У дослідах використовували бактеріальну масу тесткультур мікобактерій, які мали типові культуральні та біологічні властивості.

Бактерицидну дію препарату «DOROSEPT SUPER» щодо збудника туберкульозу Mycobacterium bovis (шт. Vallee) та атипових мікобактерій Mycobacterium fortuitum (шт. 122) випробовували в концентрації 0,5, 1,0, 2,0, 3,0, 4,0, 5,0 і 7,0 \% за експозиції 1, 5 і 24 години.

Перед початком досліду з тест-культур атипових мікобактерій $M$. fortuitum та збудника туберкульозу M. bovis, що виростали на середовищі Павловського, готували завись у концентрації 2 млрд бактеріальних тіл в $1 \mathrm{~cm}^{3}$ стерильного ізотонічного розчину. Для цього бактеріальну масу тесткультур мікобактерій переносили бактеріологічною петлею в попередньо зважені на аналітичних вагах стерильні флакони ємністю 100-200 см ${ }^{3}$ з бусами, шляхом зважування визначали масу внесених у них мікобактерій, а потім вносили необхідний об'єм стерильного ізотонічного розчину. Флакони струшували на шуттель-апараті протягом 30 -ти хвилин до одержання однорідної зависі мікобактерій.

Після цього готували робочі розчини «DOROSEPT SUPER» у вищезазначених концентраціях, які 


\section{ВЕТЕРИНАРНА МЕДИЦИНА}

вносили по $10 \mathrm{~cm}^{3}$ у флакони ємністю $20 \mathrm{~cm}^{3}$. Потім до кожного дослідного флакона окремо вносили по $0,2 \mathrm{~cm}^{3}$ зависі атипових мікобактерій. Вміст флаконів ретельно перемішували і витримували задану експозицію дії дезінфектанту. Як контроль бактерицидної дії досліджуваного препарату використовували флакон із зависсю тест-культур атипових мікобактерій, у який замість розчинів дезінфікуючого препарату вносили $10 \mathrm{~cm}^{3}$ стерильного ізотонічного розчину.

Потім з дослідних і контрольного флаконів відбирали проби по $10 \mathrm{~cm}^{3}$, переносили їх до центрифужних пробірок, які центрифугували при 3000 об/хв. протягом 30-ти хвилин.

Для припинення дії препарату в дослідних пробірках осад, що утворився після центрифугування, а також контрольну пробу двічі відмивали стерильним ізотонічним розчином шляхом центрифугування.

Після цього завись осаду висівали на поживне середовище для культивування мікобактерій. Пробірки з висівами витримували в термостаті за температури $37^{\circ} \mathrm{C}$ протягом 90 діб, і через кожні 3-5 днів після висіву проводили облік росту культур.

Визначення бактерицидних властивостей препарату «DOROSEPT SUPER» також проводили із застосуванням тест-об'єктів: дерево, керамічна плитка, батист, скло, метал з використанням тесткультури Mycobacterium bovis та застосуванням біологічного навантаження (гноївка).

На кожний тест-об'єкт наносили суміш, що містила 1 см $^{3}$ зависі тест-культури збудника туберкульозу і $0,5 \mathrm{~cm}^{3}$ стерильної гноївки. Після цього дослідні тест-об'єкти обробляли робочими розчинами дезінфектанту. На контрольні тест-об'єкти замість дезінфектанту наносили окремо стерильний ізотонічний розчин. Після витримування заданої експозиції з кожного контрольного і дослідного тестоб'єкту робили зіскрібки і змиви стерильним ізотонічним розчином у чашці Петрі, вміст яких переносили до центрифужних пробірок і центрифугували при 3000 об/хв. протягом 30 хвилин. Для нейтралізації дії препаратів осад у пробірках двічі відмивали стерильним ізотонічним розчином шляхом центифугування. Отриманий осад дослідних і контрольних проб ресуспендували в $5 \mathrm{~cm}^{3}$ стерильного ізотонічного розчину і стерильною піпеткою висівали на поживне середовище для культивування мікобактерій, а також заражали морських свинок.

Пробірки з висівами витримували в термостаті за температури $37{ }^{\circ} \mathrm{C}$ протягом трьох місяців, i через кожні 3-5 діб проводили облік росту посівів.

Біологічне дослідження виконували на здорових 5 дослідних та 5 контрольних морських свинках масою 300-350 г. Морським свинкам роздільно вводили під шкіру, в ділянці паху, в дозі $1 \mathrm{~cm}^{3}$ суспензію осаду, який одержали після обробки дослідних та контрольних тест-об'єктів з культурою Mycobacterium bovis.

За лабораторними тваринами спостерігали протягом 3-х місяців. У цей строк тварин один раз на місяць досліджували туберкуліновою пробою. Тварин, загиблих під час досліду та забитих після його завершення, досліджували патологоанатомічним та культуральним методами на туберкульоз.

\section{Результати досліджень та їх обговорення}

Результат попереднього визначення бактерицидної дії препарату «DOROSEPT SUPER» щодо атипових мікобактерій Mycobacterium fortuitum за допомогою суспензійного методу наведені в таблиці 1.

Аналіз отриманих результатів свідчить про те, що препарат «DOROSEPT SUPER» у концентрації 0,5 \% за експозиції 1-24 години має лише бактеріостатичні властивості щодо атипових мікобактерій M. fortuitum.

Бактерицидні властивості препарат «DOROSEPT SUPER» щодо M. fortuitum проявляє в концентрації 1,0-7,0 \% за експозиції 1-24 години.

Після отримання позитивних результатів попередніх дослідів остаточне визначення режиму бактерицидної дії препарату «DOROSEPT SUPER» проводили щодо збудника туберкульозу M. bovis 3 використанням тест-об'єктів: дерево, керамічна плитка, батист, скло, метал із застосуванням біологічного навантаження (гноївка). Результати цього досліду наведені в таблиці 2.

3 матеріалів таблиці 2 видно, що дезінфікуючий препарат «DOROSEPT SUPER» у концентрації 1,0-2,0 \% за експозиції 1-24 години та в концентрації 3,0-7,0 \% за експозиції 1-5 годин не знезаражує тест-об'єкти, контаміновані збудником туберкульозу M. bovis. При застосуванні препарату в концентрації 3,0-7,0 \% за експозиції 24 години він знезаражував усі тест-об'єкти.

Варто зазначити, що найбільш чутливою моделлю для проведення біопроби при дослідженні протитуберкульозних засобів є мурчаки [7], що ми і врахували при проведенні відповідних досліджень. 
ВЕТЕРИНАРНА МЕДИЦИНА

1. Результати культурального дослідження бактерицидної дї препарату «DOROSEPT SUPER» щцодо М. fortuitum

\begin{tabular}{|c|c|c|c|}
\hline \multicolumn{2}{|c|}{ Режим застосування } & \multicolumn{2}{c|}{ Результат } \\
\hline Концентрація & & Дослід & Контроль \\
\hline \multirow{3}{*}{$0,5 \%$} & 1 год & + & + \\
& 5 год & + & + \\
\hline \multirow{3}{*}{$1,0 \%$} & 24 год & + & + \\
& 1 год & - & + \\
\hline \multirow{2}{*}{$2,0 \%$} & 5 год & - & + \\
& 24 год & - & + \\
\hline \multirow{3}{*}{$3,0 \%$} & 1 год & - & + \\
& 5 год & - & + \\
\hline \multirow{3}{*}{$4,0 \%$} & 24 год & - & + \\
& 1 год & - & + \\
\hline \multirow{2}{*}{$5,0 \%$} & 5 год & - & + \\
& 24 год & - & + \\
\hline \multirow{2}{*}{$7,0 \%$} & 1 год & - & + \\
& 5 год & - & + \\
\hline & 24 год & - & + \\
\hline
\end{tabular}

Примітки: “-” - відсутність росту мікобактерій; “+” - ріст мікобактерій.

\section{2. Результати визначення бактерицидної дї препарату «DOROSEPT SUPER»} щцодо M. bovis на тест-об'єктах

\begin{tabular}{|c|c|c|c|c|c|}
\hline \multirow{2}{*}{$\begin{array}{l}\text { Режим } \\
\text { застосування }\end{array}$} & \multicolumn{5}{|c|}{ Тест-об'єкт } \\
\hline & дерево & батист & метал & плитка & скло \\
\hline $1,0 \%-1$ година & + & + & + & + & + \\
\hline 1,0 \% - 5 годин & + & + & + & + & + \\
\hline $1,0 \%-24$ години & + & - & - & - & - \\
\hline $2,0 \%-1$ година & + & + & + & + & + \\
\hline $2,0 \%-5$ годин & + & + & + & + & + \\
\hline 2,0 \% - 24 години & + & - & - & - & - \\
\hline 3,0 \% - 1 година & + & + & + & + & + \\
\hline 3,0 \% - 5 годин & + & + & + & - & - \\
\hline $3,0 \%-24$ години & - & - & - & - & - \\
\hline 4,0 \% - 1 година & + & + & + & + & + \\
\hline $4,0 \%-5$ годин & + & + & + & - & - \\
\hline $4,0 \%-24$ години & - & - & - & - & - \\
\hline 5,0 \% - 1 година & + & + & + & + & + \\
\hline 5,0 \% - 5 годин & + & + & + & - & - \\
\hline $5,0 \%-24$ години & - & - & - & - & - \\
\hline 7,0 \% - 1 година & + & + & + & + & + \\
\hline $7,0 \%-5$ годин & + & + & + & - & - \\
\hline 7,0 \% - 24 години & - & - & - & - & - \\
\hline
\end{tabular}

Примітки: “-” - відсутність росту мікобактерій; “+”- ріст мікобактерій. 


\section{ВЕТЕРИНАРНА МЕДИЦИНА}

При біологічному дослідженні були підтверджені бактерицидні властивості щодо збудника туберкульозу M. bovis досліджуваного дезінфікуючого препарату в концентрації 3,0 \% за експозиції 24 години. На внутрішньошкірне введення туберкуліну ППД для ссавців реагували лише тварини контрольної групи та при патологоанатомічному дослідженні в них були виявлені характерні для туберкульозу ураження. Культуральним дослідженням відібраного від дослідних і контрольних тварин патологічного матеріалу збудник туберкульозу $M$. bovis був виділений лише від тварин контрольної групи. Дослідні тварини на внутрішньошкірне введення туберкулінів не реагували, а з біоматеріалу після завершення досліду культур мікобактерій не було виділено.

Незважаючи на широкий асортимент дезінфікуючих засобів, усе ще залишається актуальним пошук більш екологічних і безпечних протимікробних засобів, які могли би бути альтернативою альдегідним сполукам [6]. Поряд із застосуванням хлорних деззасобів, до яких належить і досліджуваний нами препарат, необхідно зазначити, що висока гідрофобність клітинної мембрани в поєднанні з метаболічними змінами може призвести до толерантності мікобактерій до хлору [19].

Отримані нами результати досліджень розширюють спектр протитуберкульозних дезінфектантів, що своєю чергою дозволить аргументовано проводити ротацію деззасобів у загальному комплексі ветеринарно-санітарних заходів.

\section{Висновки}

У результаті бактеріологічного та біологічного досліджень бактерицидних властивостей препарату «DOROSEPT SUPER» щодо мікобактерій з'ясовано, що цей дезінфектант знищує збудника туберкульозу $M$. bovis у концентрації 3,0-7,0 \% за експозиції 24 години. Препарат «DOROSEPT SUPER» може бути застосований для проведення профілактичної та вимушеної дезінфекції приміщень у благополучних і неблагополучних щодо туберкульозу великої рогатої худоби сільськогосподарських підприємствах як 3,0 \% водний розчин за експозиції 24 години з розрахунку 1000 мл/ $\mathrm{m}^{2}$.

Перспективи подальших досліджень. Для більш детального з'ясування бактерицидної дії препарату «DOROSEPT SUPER» будуть проведені дослідження на виробництві.

\section{References}

1. Zavhorodni, A. I., Stehnii, B. T., Palii, A. P., Horzheiev, V. M., \& Smirnov, A. M. (2013). Naukovi ta praktychni aspekty dezinfektsii u veterynarnii medytsyni. Kharkiv: FOP Brovin O. V. [In Ukrainian].

2. Paliy, A. P. (2018). Efektyvnist antybakterialnoi dii dezinfikuiuchoho zasobu «Ekotsyd S» shchodo mikobakterii. Ukrainian Journal of Ecology, 8 (1), 141-147. doi: 10.15421/2018_198 [In Ukrainian].

3. Abreu, A. C., Tavares, R. R., Filipe, A. B., \& Simões, M. M. (2013). Current and emergent strategies for disinfection of hospital environments. Journal of Antimicrobial Chemotherapy, 68 (12), 2718-2732. doi: $10.1093 / \mathrm{jac} / \mathrm{dkt} 281$.

4. Abubakar, I., Lipman, M., Mc Hugh, T. D., \& Fletcher, H. (2016). Uniting to end the TB epidemic: advances in disease control from prevention to better diagnosis and treatment. BMC Med., 14, 47. doi: 10.1186/s12916-016-0599-1.

5. Best, M., Sattar, S. A., Springthorpe, V. S., \& Kennedy, M. E. (1990). Efficacies of selected disinfectants against Mycobacterium tuberculosis. Journal of Clinical Microbiology, 28 (10), 2234-2239. doi: 10.1128/jcm.28.10.2234-2239.1990.

6. Burgess, W., Margolis, A., Gibbs, S., Duarte, R.S., \& Jackson, M. (2017). Disinfectant Susceptibility Profiling of Glutaraldehyde-Resistant Nontuberculous Mycobacteria. Infection Control \& Hospital Epidemiology, 38 (7), 784-791. doi: 10.1017/ice.2017.75.

7. Clark, S., Hall, Y., \& Williams, A. (2014). Animal Models of Tuberculosis: Guinea Pigs. Cold Spring Harbor Perspectives in Medicine, 5 (5), a018572-a018572. doi: 10.1101/cshperspect.a018572.

8. Cortesia, C., Bello, T., Lopez, G., Franzblau, S., de Waard, J., \& Takiff, H. (2017). Use of green fluorescent protein labeled non-tuberculous mycobacteria to evaluate the activity quaternary ammonium compound disinfectants and antibiotics. Brazilian Journal of Microbiology, 48 (1), 151-158. doi: 10.1016/j.bjm.2016.09.009.

9. Cortesia, C., Lopez, G. J., de Waard, J. H., \& Takiff, H. E. (2010). The use of quaternary ammonium disinfectants selects for persisters at high frequency from some species of non-tuberculous mycobacteria and may be associated with outbreaks of soft tissue infections. Journal of Antimicrobial Chemotherapy, 65 (12), 2574-2581. doi: 10.1093/jac/dkq366. 


\section{ВЕТЕРИНАРНА МЕДИЦИНА}

10. Cortesia, C., Vilchèze, C., Bernut, A., Contreras, W., Gómez, K., de Waard, J., Jacobs W. R. Jr, Kremer L., \& Takiff, H. (2014). Acetic Acid, the Active Component of Vinegar, Is an Effective Tuberculocidal Disinfectant. mBio, 5 (2). doi: 10.1128/mbio.00013-14.

11. Gortázar, C., Fernández-Calle, L. M., Collazos-Martínez, J .A., Mínguez-González, O., \& Acevedo, P. (2017). Animal tuberculosis maintenance at low abundance of suitable wildlife reservoir hosts: A case study in northern Spain. Preventive Veterinary Medicine, 146, 150-157. doi: 10.1016/j.prevetmed.2017.08.009.

12. Cozad, A., \& Jones, R. D. (2003). Disinfection and the prevention of infectious disease. Am J Infect Control, 31 (4), 243-254.

13. Griffiths, P. A., Babb, J. R., \& Fraise, A. P. (1999). Mycobactericidal activity of selected disinfectants using a quantitative suspension test. Journal of Hospital Infection, 41 (2), 111-121. doi: 10.1016/s01956701(99)90048-8.

14. Mphaphlele, M., Dharmadhikari, A. S., Jensen, P. A., Rudnick, S. N., van Reenen, T. H., Pagano, M. A., Leuschner, W., Sears, T. A., Milonova, S. P., van der Walt, M., Stoltz, A. C., Weyer, K., \& Nardell, E. A. (2015). Institutional Tuberculosis Transmission. Controlled Trial of Upper Room Ultraviolet Air Disinfection: A Basis for New Dosing Guidelines. American Journal of Respiratory and Critical Care Medicine, 192(4), 477-484. doi: 10.1164/rccm.201501-0060oc.

15. Paliy, A. P., Ishchenko, K. V., Marchenko, M. V., Paliy, A. P., \& Dubin, R. A. (2018). Effectiveness of aldehyde disinfectant against the causative agents of tuberculosis in domestic animals and birds. Ukrainian Journal of Ecology, 8 (1), 845-850. doi: 10.15421/2018_283.

16. Palmer, M. V., \& Waters, W. R. (2011). Bovine Tuberculosis and the Establishment of an Eradication Program in the United States: Role of Veterinarians. Veterinary Medicine International, 2011, 1-12. doi: 10.4061/2011/816345.

17. Scanlon, M. P., \& Quinn, P. J. (2000). Inactivation of Mycobacterium bovis in cattle slurry by five volatile chemicals. Journal of Applied Microbiology, 89 (5), 854-861. doi: 10.1046/j.13652672.2000.01190.x.

18. Shinoda, N., Mitarai, S., Suzuki, E., \& Watanabe, M. (2016). Disinfectant-susceptibility of multidrug-resistant Mycobacterium tuberculosis isolated in Japan. Antimicrobial Resistance \& Infection Control, 5 (1). doi: 10.1186/s13756-016-0102-y.

19. Wang, J., Sui, M., Yuan, B., Li, H., \& Lu, H. (2019). Inactivation of two Mycobacteria by free chlorine: Effectiveness, influencing factors, and mechanisms. Science of The Total Environment, 648, 271-284. doi: 10.1016/j.scitotenv.2018.07.451.

20. Zhan, L., Tang, J., Sun, M., \& Qin, C. (2017). Animal Models for Tuberculosis in Translational and Precision Medicine. Frontiers in Microbiology, 8, 717. doi: 10.3389/fmicb.2017.00717.

21. Zumla, A., Chakaya, J., Centis, R., D’Ambrosio, L., Mwaba, P., Bates, M., Kapata, N., Nyirenda, T., Chanda, D., Mfinanga, S., Hoelscher, M., Maeurer, M., \& Migliori, G.B. (2015). Tuberculosis treatment and management-an update on treatment regimens, trials, new drugs, and adjunct therapies. The Lancet Respiratory Medicine, 3 (3), 220-234. doi: 10.1016/s2213-2600(15)00063-6.

Стаття надійшла до редакції 22.11.2019 р.

Бібліографічний опис для цитування:

Палій А. П., Завгородній А. І., Бондарчук А. О. Бактерицидні властивості засобу «DOROSEPT SUPER» щодо мікобактерій. Вісник ПДАА. 2019. № 4. C. 159-165.

(C) Палій Анатолій Павлович, Завгородній Андрій Іванович, Бондарчук Андрій Олександрович, 2019 